\title{
Tribological and mechanical properties of biobased reinforcement in a friction composite material
}

Vivek.S ${ }^{1}$, Jayakumari L S ${ }^{2}$, Stephen Bernard S ${ }^{1}$, Suresh G ${ }^{1}$, Md. Javeed Ahmed ${ }^{3}$, Arulmurugan. $\mathrm{S}^{4}$

\begin{abstract}
${ }^{1}$ Department of Mechanical Engineering, Rajalakshmi Institute of Technology, TamilNadu, Chennai, India.
${ }^{2}$ Department of Rubber and Plastics Technology, Madras Institute of Technology Campus, Anna University, TamilNadu, India.

${ }^{3}$ Department of Mechanical Engineering, B S Abdur Rahman University, TamilNadu, Chennai, India.

${ }^{4}$ Department of Mechanical Engineering, Rajalakshmi Engineering College, TamilNadu, Chennai, India.

e-mail: vivek.s@ritchennai.edu.in, stephenbernard.s@ritchennai.edu.in, jaya@mit.edu, javeed.ahmedmd@gmail.com, arulmurugan.s@rajalakshmi.edu.in
\end{abstract}

\begin{abstract}
This work presents the function of biobased ingredients (palm fiber) as reinforcement in brake pad materials. Reinforcement in brake lining improvise wear stability, wear resistance and friction optimization under a dynamic set of operating variables such as braking force, sliding speed, braking duration and braking temperature. The effect of palm fiber on physical, mechanical and tribological properties of brake pad composite is evaluated. The percentage of palm fiber is gradually increased from $2 \%$ to $12 \%$ at an interval of $2 \%$ as an alternate of rockwool fiber by varying the pressure and speed in a pin on disc tribometer. By increasing the pressure, $8 \%$ and $10 \%$ shows high friction stability at all speeds. The results show that the raise in the palm fiber quantity increases the hardness, specific gravity and heat swell and the properties, loss on ignition and porosity decreases. The SEM descriptions of the composite indicated that the smaller micro voids occurred in the sample having low palm fiber. Weight gain in the composites were also observed by exposing them in salt water, water and oil.
\end{abstract}

Keywords: Palm Fiber, Wear, Friction Stability, Brakes, SEM.

\section{INTRODUCTION}

The Intelligent product systems (IPS) suggests that commodities of service consist of substances that can be endlessly reused in technical cycles and commodities of consumption consist of substances that can be securely introduced into biological cycles [1,2]. Most parts of a car can potentially be reused as technical cycle. The brake pads are true commodities of consumption and the constituents used in brake pad must be selected positively to reduce their effect on health and environment [3-8]. Because of this, the entire world is concentrating on developing bio materials with equivalent mechanical and tribological properties, which is the main interest for this work.

Brake operates in hot and cold environments, on and off paved roads, both wet and dry conditions, with frequent stops and with different kinds of control system. The feature of friction materials is it can may perform good under one set of conditions but inadequately under another. Therefore, the development of commercial brake pad with acceptable performance is challenging [9,10]. A brake system must provide steep and stable friction, vibration free performance, low wear and noise. These properties can be obtained by using more than 10 ingredients in a single brake pad. Each constituent significantly contributes towards effective tribological properties [11].

Brake pad materials are essentially constructed by four components: a binder, filler, friction modifier and reinforcement. The main task of the binder, holds the components of a brake pad together and to prevent its constituents from crumbling apart [13-15]. Fillers are essentially used to reduce the overall cost of the material and partly to alter the brake pad properties. The role of abrasive in the brake pad is to control the friction level during braking and cleaning the glaze on the disc at the friction interface. Solid lubricant in brake pad plays the role of developing the friction film on the brake drum surface which influence the brake performance such as brake drum wear, torque variation, stopping distance and noise propensity [16].

Palm fiber have attractive performance to cost ratio has stimulated the idea of exploring their possible incorporation 
into brake pad composite materials. Palm fiber have high compressive strength, they are important determining factor in brake pad to withstand the sudden cracks. It possess good thermal conductivity, low density and improved ductility [30]. In south Asia enormous amount of Palm fibers are obtainable and clarity about the frictional properties of palm fibers are not available. Palm fiber is enriched with Potassium, Selenium, Silica, Copper, Iron, Sodium, Calcium and Manganese equally like asbestos [23-25]. Consequently, it is a viable alternate for asbestos in friction material. Its low wear rate and high hardness along with low ash content made it is a suitable alternate for friction pad material. Hardness, thermal stability and dielectric constant of the composite materials can be augmented. It is the muse behind this work to examine the impact of palm fiber on the frictional properties.

The brake pads in use now are having environmental and toxicological uncertainties which are slowly started to be recognized by the industries. This work provides substantial evidence to use bio-based composites in brake pads.

\section{PREPARATION OF FRICTION MATERIALS}

Six different composition were prepared for friction test is shown in table 1. The specimen's various parameters like friction stability, hardness, heat swell, specific gravity, porosity, loss on ignition are analyzed by pressing by using two moulds of dimensions $150 \times 150 \times 3 \mathrm{~mm}$ and $8 \times 32 \mathrm{~mm}$. Analytical balance instrument is used to measure the constituents to an accuracy of $0.1 \mathrm{~g}$. The constituents are blended at the temperature of $30^{\circ} \mathrm{C}$ at the speed of $4000 \mathrm{rpm}$ for a time lapse of sixteen minutes in electron EBR 100. A uniform mixture is prepared by a chronological mixing procedure. The procedure is stated as follows :

The fibers were initially added to a blender to make it as a large quantity to improve the mixture volume. The fibers were blended for 10 minutes then the filler and friction modifiers. For another 3 minutes the blender was made to run at the same speed by adding the filler materials. Hence the total mixing time for each composite is 16 minutes [26-29]. 500 grams of the blend is placed in a preheated die to temperature of $180^{\circ} \mathrm{C}$ and pressed with a load of $160 \mathrm{kgf} / \mathrm{cm}^{2} \mathrm{using}$ a hydraulic press of 120-ton capacity for 6 minutes. During this process to remove the volatile materials five "breathing" time was allowed. The prepared mold was cured for 2 hours each at $140^{\circ} \mathrm{C}, 160^{\circ} \mathrm{C}$ and $180^{\circ} \mathrm{C}$ respectively, thus the porosity and thermal expansion of the blend reduces.

Table 1: Formulation of friction material by varying palm fiber content

\begin{tabular}{c|c|c|c|c|c|c}
\hline $\begin{array}{l}\text { Raw Materials } \\
\text { (\% in Weight) }\end{array}$ & 2 PF & 4 PF & 6 PF & 8 PF & 10 PF & 12 PF \\
\hline Cardanol Resin & 15 & 15 & 15 & 15 & 15 & 15 \\
\hline Phenolic Resin & 5 & 5 & 5 & 5 & 5 & 5 \\
\hline Palm fiber & $\mathbf{2}$ & $\mathbf{4}$ & $\mathbf{6}$ & $\mathbf{8}$ & $\mathbf{1 0}$ & $\mathbf{1 2}$ \\
\hline Rockwool fiber & $\mathbf{1 0}$ & $\mathbf{8}$ & $\mathbf{6}$ & $\mathbf{4}$ & $\mathbf{2}$ & $\mathbf{0}$ \\
\hline Steel fiber & 8 & 8 & 8 & 8 & 8 & 8 \\
\hline CaCO & 20 & 20 & 20 & 20 & 20 & 20 \\
\hline Alumina, Cashew dust, Calcium Silicate, & 32 & 32 & 32 & 32 & 32 & 32 \\
\hline Vermiculate, Silicon & 8 & 8 & 8 & 8 & 8 & 8 \\
\hline Antimony trisulfide, Graphite & & & & \\
\hline
\end{tabular}

\subsection{Testing}

DUCOM W and F monitor was used to conduct the test and WINDUCOM data acquisition system is used for the all testing at ASTM G-99 standards. With $0.12 \mathrm{~m}$ dia grey CI as the counterpart.

The machine is an orthodox tribometer with a planar rotating disc and a pin with dead weight used for testing. The test was conducted by changing the load and sliding velocity continuously. The output parameters from the test are the friction coefficient and the specific wear rate. 

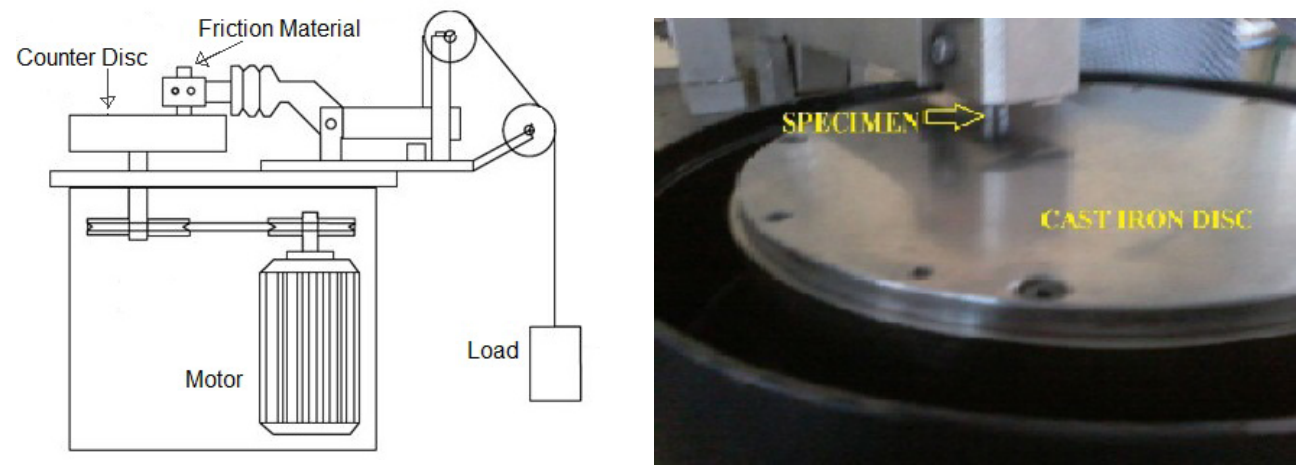

Figure 1: (a). Win Ducom wear and friction tester (b) Closed view of composite friction

A single composite material measures dia $8 \mathrm{~mm}$ and $32 \mathrm{~mm}$ length. The disc was conditioned for every test by grinding to obtain smooth surface. The testing conditions are

\begin{tabular}{c|c}
\hline Parameter & Range \\
\hline Load & $20 \mathrm{~N}$ to $40 \mathrm{~N}$ \\
\hline Velocity & $2-4 \mathrm{~m} / \mathrm{s}$ \\
\hline Distance & $6-31 \mathrm{~km}$ \\
\hline Time & $2100 \mathrm{sec}$ \\
\hline Speed & $300-700 \mathrm{rpm}$ \\
\hline
\end{tabular}

SEM analysis was carried out using the model EVO MA15 to find the blending of friction materials. At standard atmospheric condition the impact of the friction material on the ecosystem is measured at ASTM D 570-77 standard with distilled water, brine solution and Society of Automotive engineers $20 \mathrm{~W}-40$ lubrication oil.

Specific wear rate depends on applied on to cause wear, it is volume loss per unit meter per unit load. Its unit is $\left(\mathrm{m}^{3} /\right.$ $\mathrm{Nm})$. The specific wear rate is calculated by equation 1 .

$$
\text { Specifi Wear Rate }=\frac{\mathrm{V}_{\mathrm{i}}}{F^{*} s}
$$

Where, $\mathrm{V}_{\mathrm{i}}$ is the wear volume, $\mathrm{F}$ is the normal load and $\mathrm{s}$ is the sliding distance.

The friction force $(\mathrm{F})$ was observed and calculated for each pass and a average was considered for the total number of passes for each wear test, in order to determine the friction coefficient $(\mu)$. (2).

The average value of coefficient of friction $(\mu)$ of composites was calculated from the following expression equation

$$
\mu=\frac{\mathrm{F}_{\mathrm{f}}}{\mathrm{F}_{\mathrm{n}}}
$$

Where, $F_{f}$ is the average friction force and $F_{n}$ is the applied load.

Friction Stability is measured as a function of braking pressure and sliding speed by equation (3).

$$
\text { Friction Stability }=\frac{\mu_{\mathrm{avg}}}{\mu_{\max }} \times 100
$$

Where, $\mu_{\text {avg }}$ is the average friction coefficient and $\mu_{\max }$ is the maximum friction coefficient. Magnitude of percentage friction stability should be as high as possible and near to 100 .

Hardness is calculated in 'S' Scale using a Rockwell testing machine. SAE J417 standard is used to measure hardness. 
Specific gravity of the friction material was measured by the standard SAE J380. Heat Swelling was measured by SAE J160 standard. The process was repeated after heating the sample in oven at $200 \pm 2^{\circ} \mathrm{C}$ for $2 \mathrm{Hrs}$. The increase in thickness was noted as heat swell and percentage was determined.

For determining the mixing of friction materials, the composite friction surface of the samples were characterized and inspected using scanning electron microscope (SEM) model EVO MA15. With the intention of introspecting the atmospheric effect of the friction material, they were determined at room temperature and measured by ASTM D 57077 standard with salt water and water and SAE $20 \mathrm{w}-40$ oil.

\section{RESULTS AND DISCUSSION}

\subsection{Physical, mechanical and absorption properties}

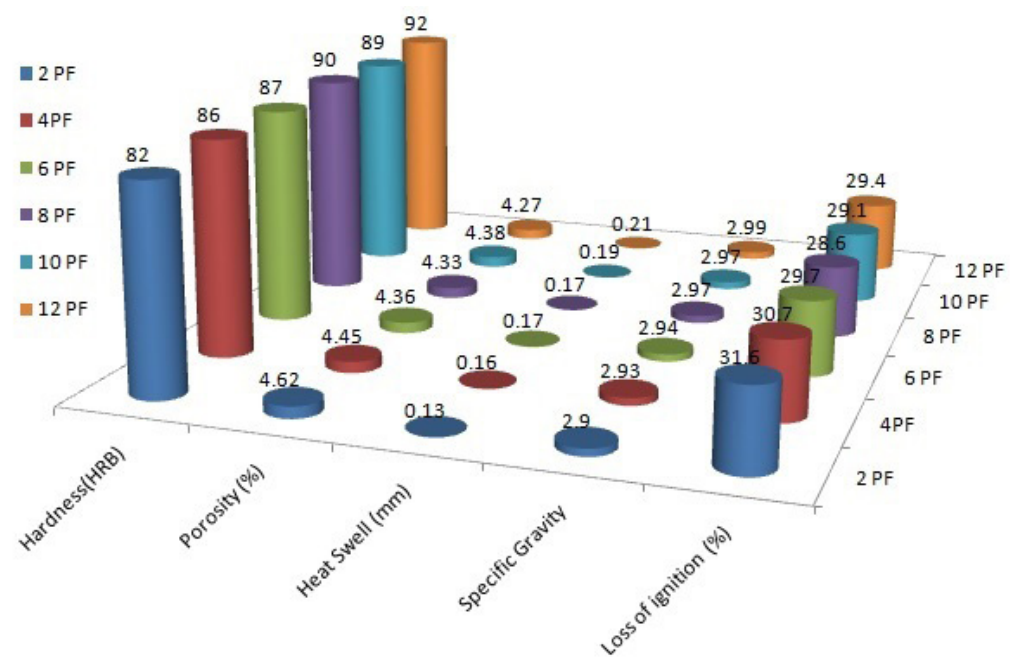

Figure 2: Properties of palm fiber material as a brake pad

Table 2: Physical, Mechanical and Absorption properties for palm fiber composite

\begin{tabular}{c|c|c|c|c|c|c}
\hline SPECIMEN & 2 PF & 4 PF & 6 PF & 8 PF & 10 PF & 12 PF \\
\hline Hardness (HRB) & 82 & 86 & 87 & 90 & 89 & 92 \\
\hline Porosity (\%) & 4.62 & 4.45 & 4.36 & 4.33 & 4.38 & 4.27 \\
\hline Heat swell (mm) & 0.13 & 0.16 & 0.17 & 0.17 & 0.19 & 0.21 \\
\hline Specific Gravity & 2.9 & 2.93 & 2.94 & 2.97 & 2.97 & 2.99 \\
\hline Loss of Ignition (\%) & 31.6 & 30.7 & 29.7 & 28.6 & 29.1 & 29.4 \\
\hline Water Absorption (\%) & 0.212 & 0.21 & 0.209 & 0.205 & 0.2 & 0.204 \\
\hline Salt Water Absorption (\%) & 0.196 & 0.162 & 0.161 & 0.171 & 0.162 & 0.162 \\
\hline SAE 20w-40 Absorption (\%) & 0.182 & 0.194 & 0.204 & 0.18 & 0.181 & 0.19 \\
\hline
\end{tabular}

The physical and mechanical properties of palm fiber loaded friction composite are presented in figure 2. Property such as porosity and loss of ignition ( $2 \mathrm{PF}>4 \mathrm{PF}>6 \mathrm{PF}>10 \mathrm{PF}>8 \mathrm{PF}>12 \mathrm{PF}$ ) decreased slightly and then increased, which is in tune to the literature range. In $8 \mathrm{PF}$ and $12 \mathrm{PF}$ due to higher content of palm fiber porosity decreases to $6.2 \%$ and $9.1 \%$ respectively. High porosity may cause premature wear and low porosity may lead to squeal [6]. The porosity must be lower than $5 \%$ for high friction composite material. If porosity decreases, specific gravity and hardness increases.. Hardness increases as palm fiber content increases in the composite material. In 2PF loss of ignition (LoI) is high which indicates the pyroprocessing of friction material was incomplete. Materials having high LoI will have high porosity which leads to absorption of moisture content from the surrounding in turn it reduces the strength of the material. 


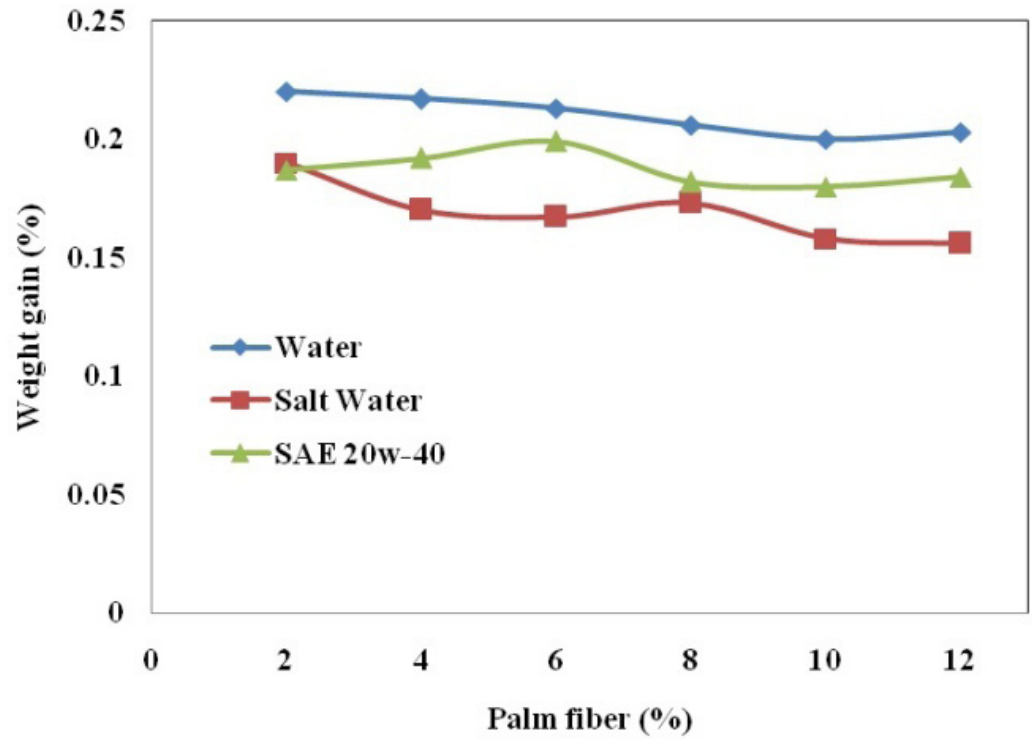

Figure 3: Absorption of palm fiber on water, salt water and lubricating oil

High content of palm fiber reduces loss of ignition. This may be due to low ash formation of palm fiber during heating. From the hardness, porosity, loss on ignition and specific gravity values none of the friction material was best in all properties. The water, salt water and SAE oil absorption tests for all compositions are presented in figure 3. $10 \mathrm{PF}$ and 12 PF shows low absorption for water and salt water. For all composites absorption was in the range of $0.16-0.22 \%$ which is in tune to the literature range[16,19].

\subsection{Friction performance}

Friction coefficient value should ranges between $0.35-0.45$ for good performance of brake pad. Here performance is also considered by effect of varying speed at each pressure on friction coefficient. The graphical representation of the time dependency of coefficient of friction is portrayed in figure 4. The addition of palm fiber increases the value of friction coefficient. Increase in COF value for the composition of palm fiber higher than $8 \%$ relates to the particulate structure of palm fiber which reduces the binding strength [17, 31]. $6 \mathrm{PF}$ and $8 \mathrm{PF}$ revealed a stable friction coefficient throughout the test. This signifies that a stable friction layer was developed after a short period.

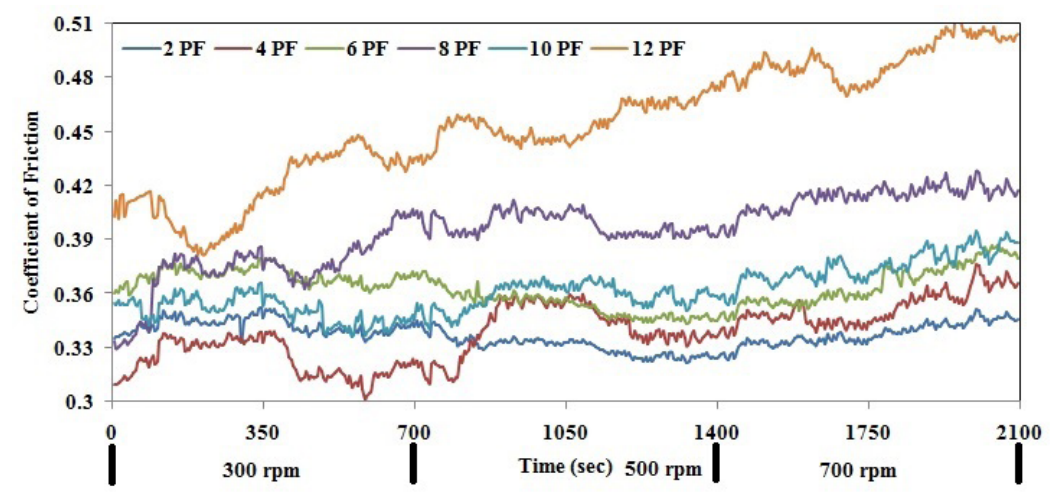

Figure 4: Effect of varying palm fiber composite for $\mathrm{COF}(2 \mathrm{MPa})$

At the beginning sudden decrease of COF is observed for $12 \mathrm{PF}$ which may be because the test was conducted under a unstable friction layer. The fluctuation of COF was higher in this time. On subjecting the $12 \mathrm{PF}$ specimen for continuous run the COF values exceeds beyond 0.45 , which tends to increase the wear rate. Similarly at high speed also the COF increases above the optimum range. For $2 \mathrm{PF}$ and $4 \mathrm{PF}$, the COF fluctuates approximately $6 \%$ when the counter disc speed is increased by $200 \mathrm{rpm}$. This implies that the increase in rotational speed of the counter disc has a direct impact on the friction level for the similar composition of the reinforcement [26]. In $1000-1300 \mathrm{rpm}$ range 6 PF shows sudden drop in friction coefficient. The sudden decrease of friction coefficient shows that the palm fiber separated from the binder resin while sliding at more rotational speed. 

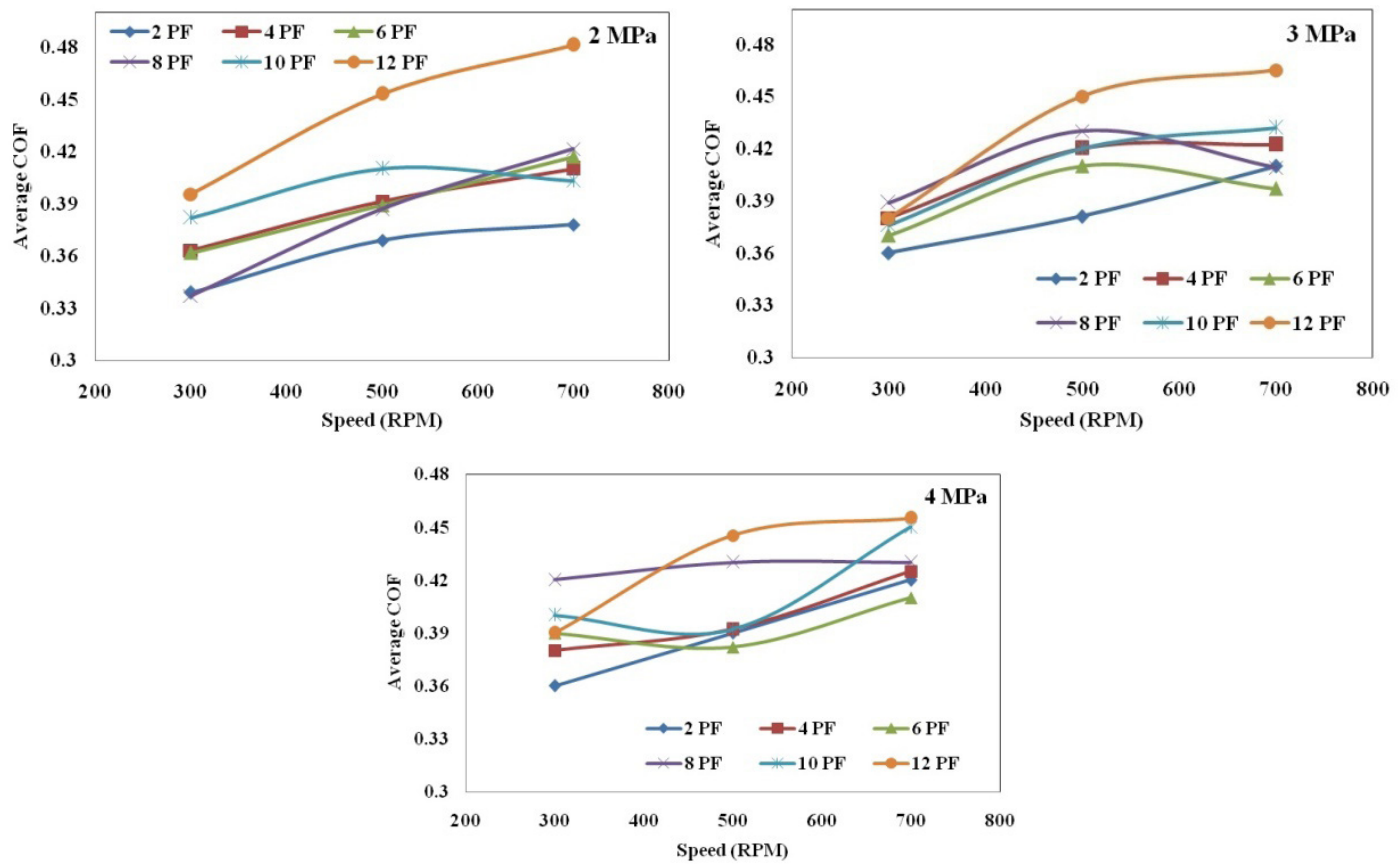

Figure 5: Friction performance of palm fiber composites under various speed and pressure (a) $2 \mathrm{MPa}$ (b) $3 \mathrm{MPa}$ (c) $4 \mathrm{MPa}$

From figure 5, the performance of composite material based on COF is in the following order

$$
\begin{array}{ll}
6 \mathrm{PF} \approx 4 \mathrm{PF}>10 \mathrm{PF}>8 \mathrm{PF}>2 \mathrm{PF}>12 \mathrm{PF} & \text { for } 2 \mathrm{MPa} \\
10 \mathrm{PF}>4 \mathrm{PF}>8 \mathrm{PF}>6 \mathrm{PF}>2 \mathrm{PF}>12 \mathrm{PF} & \text { for } 3 \mathrm{MPa} \\
8 \mathrm{PF}>4 \mathrm{PF} \approx 6 \mathrm{PF}>10 \mathrm{PF}>12 \mathrm{PF}>2 \mathrm{PF} & \text { for } 4 \mathrm{MPa}
\end{array}
$$

The best coefficient of friction observed for 6 PF, 8 PF and 10 PF may be due to high inclusion of palm fibers with limited quantity of rockwool fibers. This could also be attributed to non-formation of cold welding and rupture of asperities of the composite surfaces [26]. Hence, there were no isolated asperities captured between the sliding surfaces which could have resulted with a raise in the coefficient of friction to a required level. With increase in speed At high pressure (4MPa), up to $6 \mathrm{PF}$ there is no significant increase in $\mathrm{COF}$. It shows that the inclusion of palm fiber at low percentage does not play a role in creating an impact on COF. 2 PF and 12 PF showed excessive increase confirming its high sensitivity of COF for speed. For rest of friction material there was hardly any appreciable difference in the friction coefficient. 


\subsection{Friction Stability}
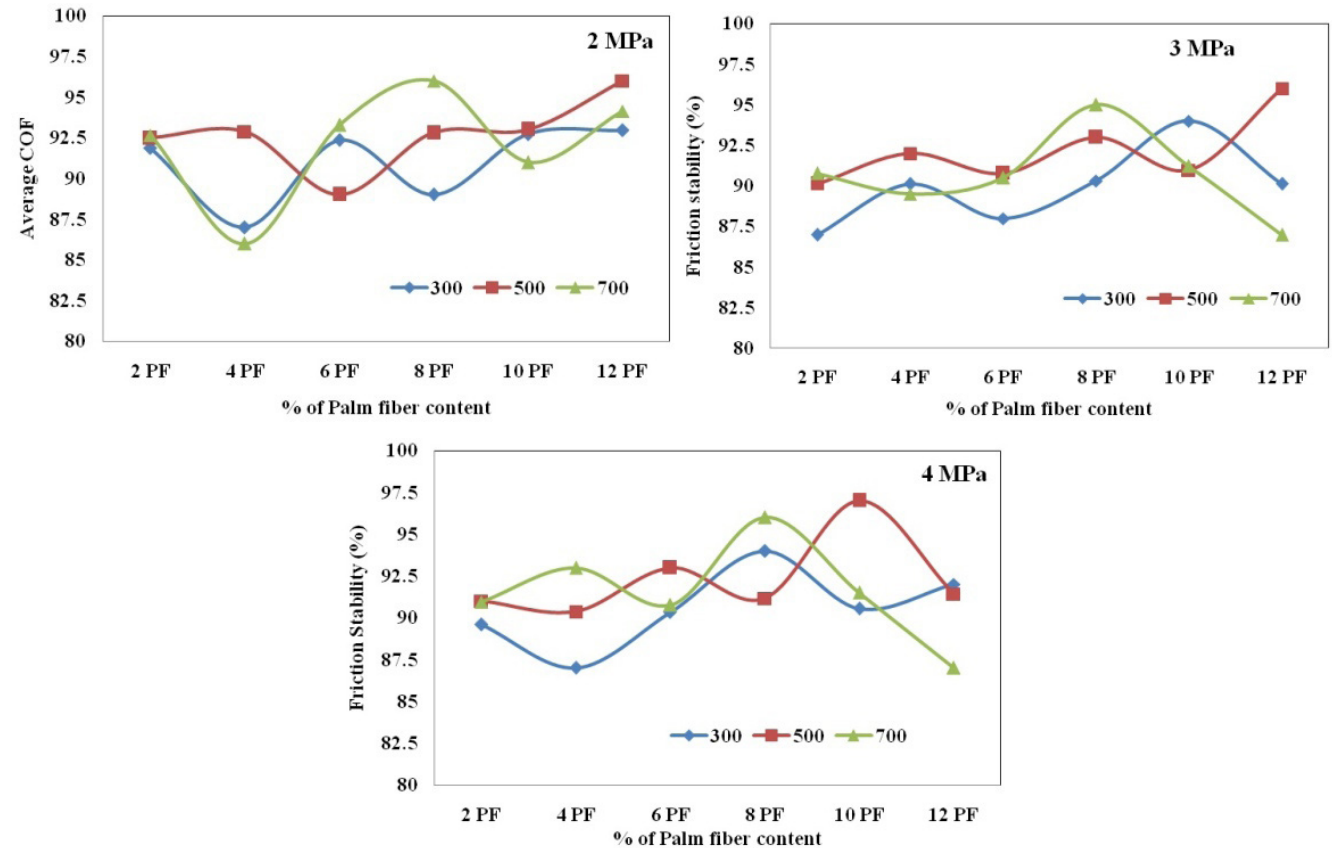

Figure 6: Friction stability of palm fiber for various operating pressure and speed (a) $2 \mathrm{MPa}$ (b) $3 \mathrm{MPa}$ (c) $4 \mathrm{MPa}$

Friction stability (FS) in terms of percentage of palm fiber content was shown in figure 6. For ideal material, FS should be as close to 100 as possible and friction coefficient range should be as small as possible. Generally, in such relations strictly regular trends are not observed and overall trends are to be considered. At all speed, FS of 4 PF was awfully poor and varied from $86 \%$ to $92.5 \%$ for $2 \mathrm{MPa}$. But it shows better result when the pressure increased for all the speed. It shows that palm fiber reduces the friction fluctuation at higher pressure. It gives comfort to the driver, when the level of friction force is same at various conditions.

Composite with lower palm fiber content shows moderate performance towards FS and it is increased by increasing the fiber content. $10 \mathrm{PF}$ showed better performance and FS was in the range of $91 \%$ to $98 \%$. At high pressure and high speed (4MPa and $700 \mathrm{RPM}$ ) friction stability of $12 \mathrm{PF}$ is 87.5 which is low compared to other samples. The reason for low friction stability of $12 \mathrm{PF}$ is at high pressure and speed, it started to disintegrate which reduces the friction between the disc and the sample. For all composites, at lower rpm and pressure the performance was poor. This may be since under mild conditions, initially full contact cannot be established.

\subsection{Wear Analysis}

For automotive brake systems in friction materials, natural fiber plays a vital role in the wear of the friction material. This is because the heat generated during brake control raises the temperature of the friction material beyond the degradation temperature of the organic constituents [13]. 


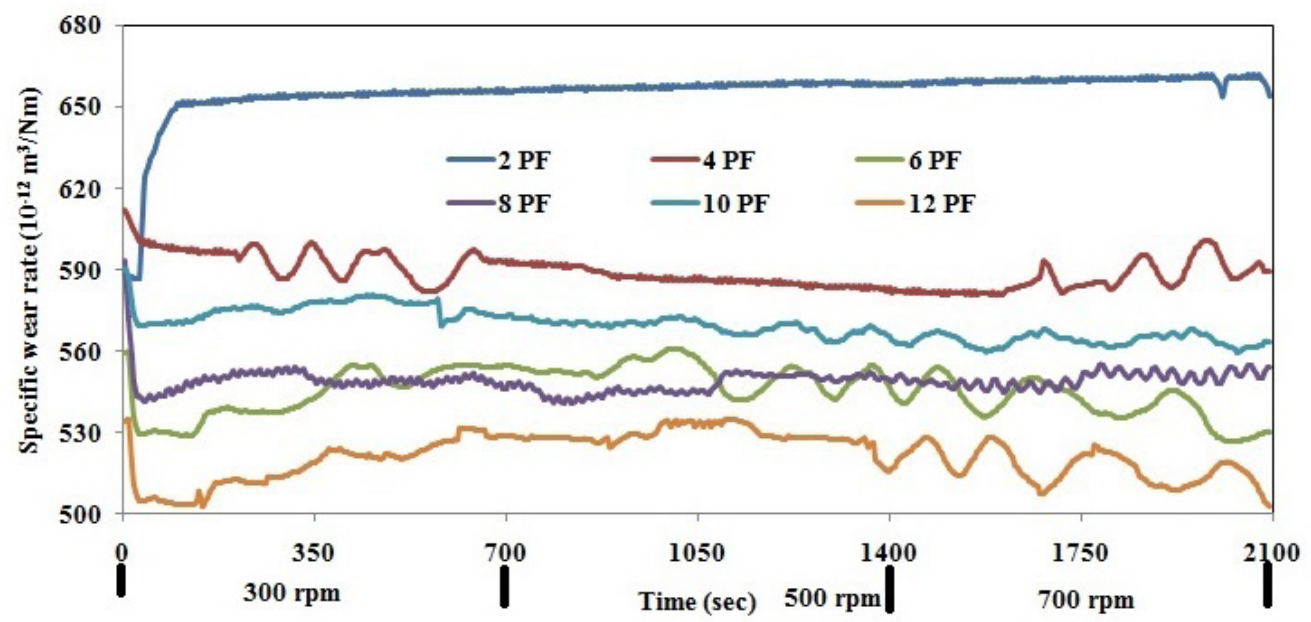

Figure 7: Effect of varying palm fiber for specific wear rate (2MPa)

The specific wear rate of the composite as a function of time is shown in figure 7. It was observed that increase in palm fiber content, reduces the weight loss and thickness loss of the composite indicating that presence of palm fiber was responsible for wear reduction in the composite material. For instance, highest wear rate were observed for $2 \mathrm{PF}$ with higher rockwool content. Initially there is sudden decrease of specific wear rate is observed for all specimen which may be due to the test was conducted under a sudden impact of load on specimen.

In case of $6 \mathrm{PF}$ and $12 \mathrm{PF}$ lowest wear rate were observed. Although this is a good result in terms of wear resistance, this condition results in higher friction coefficient values which scratch the brake drum along the sliding direction. $8 \mathrm{PF}$ and $10 \mathrm{PF}$ showed the best wear performance suggesting a longer life. This may be since palm fiber is nearly equal in proportion to that of the steel and rock wool fiber which enhance frictional performance and suppresses the wear [26]. The improvement in the wear resistance of the material is results due to the characteristic wear resistance of palm along with rockwool fiber.

\subsection{Sem analysis}
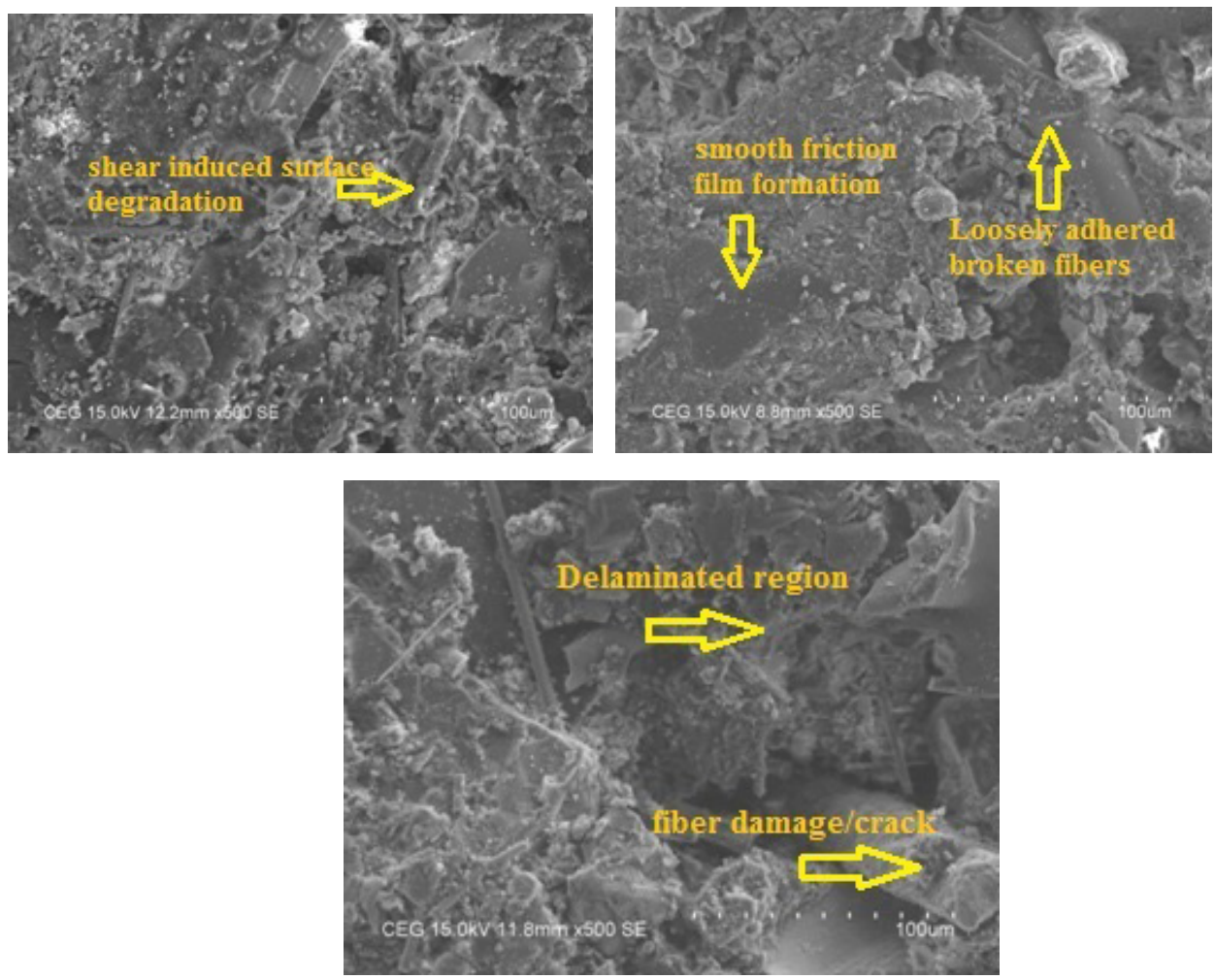

Figure 8: Worn surface showing morphology of the friction film on the brake lining after friction test (a) 6 PF (b) 8 PF (c) 10 PF 
The SEM images of the sample's worn surface after the friction test are shown in figure 8 . The SEM images of the specimens having higher content of palm fiber show that the composite containing higher palm fiber content, loosen up the fiber whereas when the palm fiber content is fewer, the fibers were tightly held up to the resin. Because of this the wear on the surface gets reduced. On 8 PF's surface we can notice the formation well leveled friction layer. It shows that the abrasive effect of the glassy phase is reduced by eliminating the sharpness of the composite [21].

In $10 \mathrm{PF}$ severe pitting action and delaminated region, similar to three-body abrasive wear, clearly identified on the layer of the pad. These damaged fiber were detached by abrassion and sliding action caused by the contact with the counter steel disc at different sliding speeds and pressure. On comparing the $8 \mathrm{PF}$ specimen with the $10 \mathrm{PF}$, it shows more amount of fiber damage. But in $8 \mathrm{PF}$ freely clung broken fibers are noticed. Whereas in $6 \mathrm{PF}$ specimen the changes in the surface is noticed as a thin film of solid. Friction between the surface and the CI disc results in high fiber disintegration. Small cavities were formed in the specimens having lesser palm fiber content. But, in the specimens having more amount of palm fiber content the size of cavities is larger. The reason behind this is that the palm fiber particles tends to loosen up. It shows the fiber coherence is more, in turn it increases the wear. In 6 PF the particles, which escaped the shear induced surface integration create the friction interface layer. This forms a ablative wear and found in overstrained and heated surfaces on the outer surfaces of brake pad materials.

\section{CONCLUSIONS}

From the investigation, it was observed that friction stability of Palm fiber composite is high at high pressure, and therefore reduces fluctuation for continuous sliding. $8 \mathrm{PF}$ and $10 \mathrm{PF}$ exhibited the best wear performance compared to other friction material, and these types of reinforced specimen exhibits a longer life. This may be because of the palm fiber is nearly equal in proportion to that of the steel and rock wool fiber.

$2 \mathrm{PF}$ and $4 \mathrm{PF}$ shows the lower COF value less than 0.36 throughout the sliding, and hence the contact connecting the pad and rotor was found to be poor. None of the combination presented in this study are not best in all the properties. In a specimen, if hardness, heat swell and specific gravity increases in turn there is a reduce in the properties of loss on ignition and porosity.

$8 \mathrm{PF}$ and $10 \mathrm{PF}$ were considered as optimized composition and were subjected to produce brake pad composites to do the further studies.

\section{BIBLIOGRAPHY}

[1] PATNAIK, A., KUMAR, M., BHABANI K, et al. Performance sensitivity of hybrid phenolic composites in friction braking: Effect of ceramic and aramid fibre combination. Wear. 2010; 269: 891-899. http://dx.doi.org/10.1016/j. wear.2010.08.023.

[2] RAMOUSSE, S., HOJ, J.W., SORENSEN, O.T. Thermal Characterization of Brake Pads. Journal of Thermal Analysis and Calorimetry. 2001; 64: 933-943. http://dx.doi.org/10.1023/A:1011575013779.

[3] GANGULY, A., GEORGE, R.. Asbestos free friction composition for brake linings. Bulletin material science. 2008; 31:19-22. http://dx.doi.org/10.1007/s12034-008-0004-6.

[4] CHO, K.H., CHO, M.H., KIM, S.J., JANG, H.. Tribological properties of Potassium Titanate in the brake friction materials; Morphological effects. Tribology Letters. 2008; 32: 59-66. http://dx.doi.org/10.1007/s11249-008-9362-x

[5] CHAN, D., STACHOWIAK, G.W., 'Review of automotive brake friction materials. Proceeding of the Institution of Mechanical Engineers, Part D: J. Auto. Eng. 2004; 218: 953-966. http://dx.doi.org/10.1243/0954407041856773.

[6] CHO, M.H., KIM, S.J., BASCH, R.H., et al. Tribological study of gray cast iron with automotive brake linings: The effect of rotor microstructure. Tribology International, 2003; 36: 537-545. http://dx.doi.org/10.1016/S0301-679X(02)00260-8.

[7] STEPHEN BERNARD, S., JAYAKUMARI, L.S. Pressure and temperature sensitivity analysis of palm fiber as a biobased reinforcement material in brake pad. Journal of Brazilian Society of Mechanical Science and Engineering. 2018; 40:152. http://dx.doi.org/10.1007/s40430-018-1081-0.

[8] RONGPING, Y., PETER, F., YAFEI, L.. Performance and evaluation of eco-friendly brake friction materials. Tribology International. 2010; 43: 2010-2019. http://dx.doi.org/10.1016/j.triboint.2010.05.001.

[9] EL-TAYEB, N.S.M., LIEW, K.W. Effect of water spray on friction and wear behaviour of noncommercial and commercial brake pad materials. Wear. 2008; 208: 135-144. http://dx.doi.org/10.1016/j.jmatprotec.2007.12.111. 
[10] HAN Y, TIAN X, YAN, Y. Effect of ceramic fiber on the friction performance of automotive brake lining materials. Tribology Transactions. 2008; 51: pp. 779-783. http://dx.doi.org/10.1080/10402000802011778.

[11] STEPHEN BERNARD, S., JAYAKUMARI, L.S. Effect of the Properties of Natural Resin Binder in a High Friction Composite Material. Polimeros- Ciencia Tecnologia. 2014. 24; 2: 149-152. http://dx.doi.org/10.4322/polimeros.2014.038.

[12] HEE, K.W., FILIP, P. Performance of ceramic enhanced phenolic matrix brake lining materials for automotive brake linings. Wear. 2005; 259: 1088-1096. http://dx.doi.org/10.1016/j.wear.2005.02.083.

[13] BIJWE, J., KUMAR, M.. Optimization of steel wool contents in non-asbestos organic (NAO) friction composites for best combination of thermal conductivity and tribo-performance. Wear. 2007; 263: 1243-1248. http://dx.doi.org/10.1016/j. wear.2007.01.125.

[14] INGO, G.M., D’UFFIZI, M., FALSO, G., et al.Thermal and microchemical investigation of automotive brake pad wear residues. Thermochimica Acta. 2004; 418: 61-68. http://dx.doi.org/10.1016/j.tca.2003.11.042.

[15] MALHOTRA, V.M., VALIMBE, P.S., WRIGHT, M.A. Effects of fly ash and bottom ash on the frictional behaviour of composites. Fuel, 2002; 81: 235-44. http://dx.doi.org/10.1016/S0016-2361(01)00126-0.

[16] IKPAMBESE, K.K., GUNDU, D.T., TULEUN, L.T. Evaluation of palm kernel fibers (PKFs) for production of asbestos-free automotive brake pads. Journal of King Saud University - Engineering Sciences. 2016; 28: 110-118. http:// dx.doi.org//10.1016/j.jksues.2014.02.001.

[17] STEPHEN BERNARD, S. Investigation on Performance, Combustion and Emission Characteristics of a Turbocharged Low Heat Rejection DI Diesel Engine with Extended Expansion Concept. SAE Technical Paper 2009-28-0006. 2009. http://dx.doi.org/10.4271/2009-28-0006.

[18] MOHANTY, S., CHUGH, Y.P. 2007. Development of fly ash-based automotive brake lining. Tribology International. 2007; 40: 1217-24. http://dx.doi.org/10.1016/j.triboint.2007.01.005.

[19] ROSA, A.G.A., MORETO, J.A., MANFRINATO, M.D., et al.Study on friction and wear behavior of SAE 1045 steel, reinforced nylon 6.6 and NBR rubber used in clutch disks. Material Science. 2014; 17: 1397-1403. http://dx.doi. org/10.1590/1516-1439.282714.

[20] JANG, H., LEE, J.S., FASH, J.W. Compositional effects of the brake friction material on creep groan phenomena. Wear. 2001; 251: 1477-1483. http://dx.doi.org/10.1016/S0043-1648(01)00786-4

[21] STEPHEN BERNARD, S., JAYAKUMARI, L.S. Effect of Rockwool and Steel fiber on the Friction Performance of Brake Lining Materials. Materia- Rio de Janeiro. 2016; 21: 656-665. http://dx.doi.org/10.1590/S1517-707620160003.0063.

[22] KOLLURI, D.K., BOIDIN, X., DESPLANQUES, Y., et al. Effect of Natural Graphite Particle size in friction materials on thermal localisation phenomenon during stop-braking. Wear, 2010; 268: 1472-1482. http://dx.doi.org/10.1016/j. wear.2010.02.024.

[23] CHO, M.H., KIM, S.J., KIM, D., et al.. Effects of ingredients on tribological characteristics of a brake lining: an experimental case study. Wear. 2005; 258: 1682-1687. http://dx.doi.org/10.1016/j.wear.2004.11.021.

[24] RUZAIDI, C.M., KAMARUDIN, H., SHAMSUL, J.B., et al.Mechanical Properties and Morphology of Palm Slag, Calcium Carbonate and Dolomite Filler in Brake Pad Composites. Applied Mechanics and Materials. 2013; 313: 174-178. http://dx.doi.org/10.4028/www.scientific.net/AMR.328-330.1636.

[25] KCHAOU, M., SELLAMI, A., ELLEUCH, R., et al.Friction characteristics of a brake friction material under different braking conditions. Journal of material and design. 2013; 52: 533-540. http://dx.doi.org/10.1016/j.matdes.2013.05.015.

[26] BLAU, P.J., MEYER III, H.M.. Characteristics of wear particles produced during friction tests of conventional and unconventional disc brake material. Wear. 2003; 255: 1261-1269. http://dx.doi.org/10.1016/S0043-1648(03)00111-X.

[27] ERTAN, R., YAVUZ, N. An experimental study on the effects of manufacturing parameters on the tribological properties of brake lining materials. Wear, 2010; 268: 1524-1532. http://dx.doi.org/10.1016/j.wear.2010.02.026.

[28] RUZAIDI, C.M., KAMARUDIN, H., SHAMSUL, J.B., et al.Comparative study of thermal, compressive, and wear properties of palm slag brake pad composites with other fillers. Australian Journal of Basic Applied Sciences. 2011; 5: 790-796.

[29] MUTLU, O., EIDOGAN, FINDIK, F. Production of ceramic additive automotive brake lining and investigation of its braking characteristics. International journal of Tribology. 2005;57:84-92.http://dx.doi.org/10.1108/00368790510583401.

[30] KROEHONG, W., DAMRONGWIRIYANUPAP, N., SINSIRI, T., JATURAPITAKKUL, C. The effect of palm oil fuel ash as a supplementary cementitious material on chloride penetration and microstructure of blended cement paste. Arabian Journal of Science and Engineering. 2016; 41: 4799-4808. https://doi.org/10.1007/s13369-016-2143-1 
[31] STEPHEN BERNARD, S., MD.JAVEED AHMED, DASAPRAKASH, J., SAROJ NITIN MR, VIVEK, S., KANNAN, G.K.. Friction and Wear Properties of Bio-Based Abrasive in a High-Friction Composite Material, Lecture Notes in Mechanical Engineering. 2019; 577-585. https://doi.org/10.1007/978-981-13-6374-0_63

\section{ORCID}

Vivek S

https://orcid.org/0000-0002-2910-4597

Stephen Bernard S

Jayakumari LS

https://orcid.org/0000-0003-1321-6989

Javeed Ahmed MD

https://orcid.org/0000-0003-4789-4112

Arulmurugan S

https://orcid.org/0000-0002-0382-2873

Suresh G

https://orcid.org/0000-0002-5124-5740

https://orcid.org/0000-0001-6877-3999 